\title{
«Ukok princess» in Anokhin National museum of the Altai Republic: returning, exhibiting
}

\author{
DOI: 10.31551/2410-2725-2018-4-3-378-386
}

\section{Belekova Emiliya Alexeevna}

Deputy director for scientific work of Budgetary institution of Altai Republic «National museum of Altay Republic of A.V. Anokhin». 649006 Altay Republic Gorno-Altaysk, Choros-Gurkin St., 46. E-mail: musey_anohin@mail.ru

\begin{abstract}
In 1993 in Ukok Plateau of the Kosh-Agachsky district of Altay Republic, in burial of the 53rd centuries B.C. Novosibirsk archeologists found a mummy of the young woman of pazyryksky culture of the Scythian period which journalists christened "the Ukoksky princess". The woman lay on a felt laying with a pillow under the head, on the right side in the pose sleeping with the legs and hands crossed on a stomach which are slightly bent in knees, and was covered by a fur cover with appliques from a gold foil in the form of a vegetable ornament. In ears "the Ukoksky princess" had gold earrings, all brush died was covered with pearls. Distinctive feature of a mummy is the rich tattoo on abody. It is hardly then the Novosibirsk scientists could assume that the discovery made by them will get a response not only from experts, but also will touch national issues among indigenous people of Mountain Altay - Altaians. Archaeological works became a basis of the broad social conflict.

In the article history of return of a mummy of the young woman of the pazyryksky culture of the Scythian period to Altay Republic which is dug out in 1993 on mountain Ukok Plateau is considered. The author tells about the social resonance caused by exhibiting of a mummy. Keywords: excavation; the mummified woman's body; «Ukok princess»; exhibiting.
\end{abstract}

\section{А.В. Анохин атындағы Алтай Республикалық ұлттық мұражайына «Укок ханшайымының»: оралуы, экспонирование}

\section{Белекова Эмилия Алексеевна}

Алтай Республикасының "А.В. Анохин атындағы Алтай Республикалық ұлттық мұражайы" бюджеттік мекемесінің ғылыми жұмыс жөніндегі директордың орынбасары 649006 Алтай Республикасы, Горно-Алтайск қ, Чорос-Гуркина қ, 46. E-mail: musey_anohin@mail.ru

\begin{abstract}
Аңдатпа. 1993 жылы Алтай Республикасының Кош-Агач ауданындағы Укок қыратында Новосибирск археологтары б.з.д. 5-ші ғасырларда жерленген, Скиф кезеңіндегі пазырық мәдениеті дәуірінде өмір сүрген жас әйелдің мумиясын тапты, оны журналистер «Укок ханшайымы» деп атады. Әйел адам киіз төсеніште басына жастық қойылып, оң жағына қисайып ұйықтаған тәрізді аяқтары аздап бүгіліп, қолдары ішіне қарай айқастырылып, үстіне гүлді өрнек түріндегі алтын құрастырмамен қапталған жүн төсенішімен жабылған болатын. «Укок ханшайымының» құлақтарында алтын дөңгелек сырғалар болды, оның бар білегі меруертпен әшекейленген. Мумияның айрықша ерекшелігі - денесінде бай тату өрнектер бар.

Новосибирск ғалымдары олардың ашқан жаңалығы тек қана мамандарға ғана емес, сонымен қатар түбегейлі Алтайдың байырғы тұрғындары - алтайлықтардың ұлттық мәселелеріне де әсерін тигізетінін болжай алмады. Археологиялық жұмыс кең ауқымды әлеуметтік жанжалдың негізі болды.

Бұл мақалада Скиф кезеңіндегі мәдениетінің 1993 жылы жоғары Укок шыңында табылған жас әйелдің мумиясының Алтай Республикасына оралуы туралы баяндалады. Автор мумияның әсерінен туындаған әлеуметтік резонанс туралы әңгімелейді.
\end{abstract}

Түйін сөздер: қазба жұмыстары; мумификацияланған әйел денесі; «Укок ханшайымы»; экспонирование.

\section{«Укокская принцесса» в Национальном музее Республики Алтай имени А.В. Анохина: возвращение, экспонирование}

\section{Белекова Эмилия Алексеевна}

заместитель директора по научной работе Бюджетного учреждения Республики Алтай «Национальный музей Республики Алтай имени А.В. Анохина». 649006 Республика Алтай г. ГорноАлтайск, ул. Чорос-Гуркина, 46. E-mail: musey_anohin@mail.ru 
Абстракт. В 1993 году на плоскогорье Укок Кош-Агачского района Республики Алтай новосибирскими археологами в захоронении V-III веков до нашей эры была найдена мумия молодой женщины пазырыкской культуры скифского периода, которую журналисты окрестили «Укокской принцессой». Женщина лежала на войлочной подстилке с подушкой под головой, на правом боку в позе спящей, со слегка согнутыми в коленях ногами и скрещенными на животе руками, и была укрыта меховым покрывалом с аппликациями из золотой фольги в виде растительного орнамента. В ушах у «Укокской принцессы» были золотые серьги-кольца, вся кисть умершей была покрыта жемчугом. Отличительной особенностью мумии является богатая татуировка на теле.

Вряд ли тогда новосибирские ученые могли предположить, что сделанное ими открытие найдет отклик не только у специалистов, но и затронут национальные проблемы среди коренного населения Горного Алтая - алтайцев. Археологические работы стали основой широкого социального конфликта.

В статье рассматривается история возвращения в Республику Алтай мумии молодой женщины пазырыкской культуры скифского периода, раскопанной в 1993 году на высокогорном плато Укок. Автор рассказывает о социальном резонансе, вызванном экспонированием мумии.

Ключевые слова: раскопки; мумифицированное тело женщины; «Укокская принцесса»; экспонирование.

\title{
әОЖ/ УДК 069.8
}

\author{
«Укокская принцесса» \\ в Национальном музее Республики Алтай имени А.В. Анохина: \\ возвращение, экспонирование
}

\section{Э.А. Белекова}

В 1993 году на плоскогорье Укок Кош-Агачского района Республики Алтай новосибирскими археологами в захоронении V-III веков до нашей эры была найдена мумия молодой женщины пазырыкской культуры скифского периода, которую журналисты окрестили «Укокской принцессой». На протяжении двух десятилетий ученые хранили мумию в новосибирском Академгородке, в Музее Института археологии и этнографии Сибирского отделения РАН.

Открытия новосибирских исследователей явились одним из самых значимых мировых достижений исторической науки конца XX века. Раскопки дали ценный археологический и генетический материал по пазырыкской культуре скифского времени.

Курган представлял собой полуразрушенный памятник, который еще в древности пытались ограбить. В XX веке памятник подвергся разрушению в связи с сооружением пограничных коммуникаций.

В яме под курганом были обнаружены погребенные еще в тюркскую эпоху молодой человек и подросток (девочка), из вещей сохранились два железных ножа, два глиняных сосуда, фррагменты золотой фольги. В мир иной их сопровождали три лошади, но главное было в том, что под этим, сооруженным позже, настилом располагалось более раннее захоронение скифской эпохи.

На самом дне ямы стояла срубленная из лиственницы погребальная камера, вдоль южной стенки стоял массивный саркофаг-колода, украшенный снаружи кожаными аппликациями, изображающими оленей. За северной стенкой погребальной камеры лежали костяки пяти лошадей, костяк шестой лошади лежал сверху, на перекрытии сруба. Таким количеством ездовых коней мог обладать лишь человек весьма высокого социального статуса.

В самой же погребальной камере оказался лед, на века сковавший захоронение знатной женщины. Женщина лежала на войлочной подстилке с 
подушкой под головой, на правом боку в позе спящей, со слегка согнутыми в коленях ногами и скрещенными на животе руками, и была укрыта меховым покрывалом с аппликациями из золотой фольги в виде растительного орнамента. В захоронении было обнаружено также несколько предметов: серебряное зеркало, сосуды из дерева, рога, глины, резные деревянные фигурки крылатых барсов, оленей, птички, украшавшие головной убор, блюдечко с кориандром. В ушах у «Укокской принцессы» были золотые серьги-кольца, вся кисть умершей была покрыта жемчугом. Отличительной особенностью мумии является богатая татуировка на теле.

На левом плече женщины изображено фантастическое животное: копытное с клювом грифона, стилизованными рогами козерога и оленя, украшенными головками грифронов. Животное показано с «перекрученным» туловищем. Ниже в такой же позе изображен баран с закинутой назад головой. У его задних ног сомкнулась пасть пятнистого барса с длинным закрученным хвостом». Татуировки имелись на части фраланг пальцев обеих рук.

Аналогичные татуировки были на мумифицированном теле шестидесятилетнего монголоидного вождя из Второго Пазырыкского кургана, раскопанного С.И. Руденко в 1948 году. Изображения присутствовали на обеих руках, в верхней части спины, на голени погребенного и представляли фригуры реальных и фантастических животных, рыб.

На левом плече мумии молодого мужчины, раскопанного на плато Укок 1995 году в могильнике Верх-Кальджин было изображено копытное животное, как бы перекинутое через плечо.

Ученые считают, что татуировки вряд ли являлись чем-то необычным для пазырыкцев. На всех обнаруженных в Горном Алтае пазырыкских мумиях были обнаружены татуировки, но место их нанесения, подбор образов были различными и зависели от пола, положения в обществе, социальных функций. Столь значимые несмываемые образы зверей, нанесенные на тело в результате мучительной процедуры, делали человека причастным к великим мистическим тайнам его общества.

Вряд ли тогда новосибирские ученые могли предположить, что сделанное ими открытие найдет отклик не только у специалистов, но и затронут национальные проблемы среди коренного населения Горного Алтая - алтайцев. Археологические работы стали основой широкого социального конфликта.

Первоначально население прореагировало на раскопки неоднозначно. Часть алтайского общества одобрила новые археологические открытия из-за того, что они проливают свет на древнее прошлое Горного Алтая, этноса. Из-за сенсационного освещения событий СМИ на фоне постсоветского поиска этнических маркеров многие люди восприняли «Ледяную деву» как благородную воительницу. В газетах появились сообщения, что археологи работали «на месте древнего святилища, которому поклоняются народы Алтая и откопали саму «княжну Кадын» - прародительницу алтайского народа». Женщина, похороненная 2,5 тыс. лет назад на плато Укок, соединилась в сознании народа с богатыркой Очи-Бала, т.е. стала персонажем одноименного алтайского героического эпоса, которая спасла свой народ от порабощения.

Эта идея стала спонтанно культивироваться и сформировалось мнение, что археологи раскопали мифическую «алтайскую принцессу». Современная мифология в 1990-е годы вошла в общественную, культурную и даже политическую жизнь населения Республики Алтай.

1990-е годы в истории России - время демократических преобразований во многих областях общественно-политической жизни. В 1991 году Горно- 
Алтайская автономная область стала самостоятельным субъектом Российской Федерации - преобразована в Республику Алтай. На этом фоне в Горном Алтае происходит ряд событий, тесно взаимосвязанных, взаимообусловленных, отразившихся на этническом самосознании алтайцев. Это борьба против строительства ГЭС на реке Катунь, проведение общенародного праздника «Эл Ойын», ежегодные праздники алтайских родов-сеоков, где избираются главы родов - зайсаны, создание алтайской общественной организации «Эне Тил» (родной язык), видевших одну из задач своей деятельности в возрождении алтайского языка, повышении его официального статуса, актуализации традиционных ценностей алтайцев (Еркинова 2013: 133).

Именно в этот период возрождения интереса к своей истории, культуре весьма символичным является появление имени «Укокской принцессы». Со временем она превращается в своеобразный национальный символ.

Согласно работе «Этнопсихология» А.А. Налчаджяна «создание новых национальных символов является не только реальным, но и необходимым этнопсихологическим процессом и становится особенно динамичным и продуктивным в периоды национального возрождения, консолидации межэтнических конфрликтов», «появление символов связаны с развитием этнического самосознания, его переходом на новый и более высокий уровень» (Налчаждян 2004: 144).

Таким образом, археологические находки стали неотьемлемой частью возрождающейся алтайской культуры, национального самосознания, предметом гордости за свою богатую и древнюю историю, национального достоинства и т.д.

С другой стороны, определенная часть интеллигенции и некоторые лидеры выразили свое глубокое неудовольствие работами археологов и потребовали перезахоронения мумий и введения моратория на археологические раскопки. Наряду с протестами раскопкам, они использовали нерешенную судьбу «Укокской принцессы» в качестве причины широкого спектра несчастий. Диапазон несчастий был от утопления людей, автомобильных катастроф, самоубийств до периодов засухи, аварийной посадки вертолета, транспортировавшей мумию и т.д. Даже фредеральные события, как война в Чечне, кризисы связывались с раскопками. Самой главной причиной катастроф назывался вывоз мумии с родных мест на чужбину. Конфликт разгорелся с новой силой после землетрясения, которое потрясло Юго-Восточный Алтай осенью 2003 года с эпицентром недалеко от села Бельтир Кош-Агачского района. Подземные толчки, ощутимые на Алтае и в сопредельных регионах в течение нескольких месяцев подряд, заставили около 1400 жителей Бельтира переехать в новое место.

Разрушения и политизация вопроса в СМИ вызвали волну по всей республике. Алтайцы высказывали свои требования о безотлагательном возвращении «Укокской принцессы» на родину.

Когда в дискуссии начали использоваться результаты ДНК-анализа и данные физической антропологии, пропасть между археологами и коренным населением еще более углубилась. Публичные заявления таких ведущих ученых, как директора Института археологии Российской Академии наук Н.А. Макарова, о том, что современные алтайцы не имеют прав препятствовать археологическим исследованиям, поскольку не имеют никакой биологической связи с мумией, еще больше поляризовали конфликтующих. Полученные данные и последующие выступления археологов, раскопавших укокские мумии, в прессе были интерпретированы алтайцами как отрицание их связи с предками и права претендовать на наследие, а также как умаление истории алтайцев, признавая их чуть ли не пришельцами на родине, т.е. одним из многих народов, которые мигрировали на Алтай. 
В Республике Алтай полемика про наследие стала тогда символичной и доминировала в повседневных разговорах и политических дебатах в ходе предвыборной борьбы. В результате открытого противостояния между алтайской интеллигенции и археологами, Государственное Собрание - Эл Курултай Республики Алтай рассмотрело «Обращение жителей Республику Алтай по поводу археологических раскопок на плоскогорье Укок» и приняло постановление № 22-65 от 10 июля 1997 года «О запрете раскопок курганов в КошАгачском районе». Это постановление послужило в основном как мораторий на раскопки, что привело к прекращению ряда научно-исследовательских проектов, включая проект по Укоку. В 2002 году юридический контекст этого моратория изменился: был принят фредеральный закон, которому должны соответствовать региональные законы по наследию. ФЗ предусматривает, что археологические памятники являются объектами федерального значения. В итоге мораторий 1997 году был отменен.

По поводу возвращения мумии с самого начала среди населения и представителей государственной власти республики существовали две полярные точки зрения. Первая точка зрения заключалась в передаче мумии в республиканский музей, с тем, чтобы оны была доступна для обозрения. Вторая точка зрения заключалась в необходимости перезахоронения мумии, которое «освободит ее дух и пресечет надругательство над телом». На запрос Агентства по культурно-историческому наследию (АКИН) Республики Алтай о передаче мумии в республиканский музей, Институт археологии и этнографии СОРАН уверил, что после завершения всех необходимых антропологических и генетических исследований в Москве и Новосибирске мумия будет передана.

Республиканский краеведческий музей начал подготовительные работы для хранения и экспонирования мумии. В 1999 году в соответствии с Указом Президента Российской Федерации «О мерах по усилению государственной поддержки культуры и искусства в Российской Федерации» музею был присужден грант президента. По смете расходов средства, выделенные на грант, были предусмотрены на приобретение оборудования: саркофага-витрины, кондиционеров для поддержания температурно-влажностного режима. Для подготовки экспозиционного зала площадью 100 кв.м. - ремонта, проведения системы пожарно-охранной сигнализации, изготовления экспозиционного оборудования и т.д. Правительством Республики Алтай были выделены дополнительные средства. Условия хранения, рекомендации были разработаны Научноисследовательским центром биологических технологий (г. Москва).

Согласно Протоколу о сотрудничестве в сфере сохранения и использования историко-культурного наследия между Министерством культуры Республики Алтай и Институтом археологии, подписанного в 1998 году Институт обязался передать мумию в республиканский музей после завершения ремонта специального помещения.

Но в 2000 году Институт сообщил, что, подписав указанный выше Протокол, превысил свои полномочия и этот вопрос будет рассматриваться на уровне Президиума СО РАН и Главы Республики Алтай. На этом завершается очередной этап борьбы за возвращение мумии на Алтай и начинается новый.

Именно с этого времени берет начало вопрос о реконструкции здания музея. В 1999 году республиканский музей для участия в «Программе социальноэкономического развития РА на период до 2005 г.» готовит вопрос по проблеме «создании условий для сохранения особо ценного объекта национального культурно-исторического наследия «Укокской принцессы» в Республиканском краеведческом музее имени А.В. Анохина». В результате указанное мероприя- 
тие было включено в многолетнюю перспективную программу развития Республики Алтай.

В конце 2002 года в бюджете на 2003 год были предусмотрены средства на проектно-сметную документацию реконструкции здания музея, расширения площадей под фондохранилища, экспозиционно-выставочные работы и строительства мавзолея для «Укокской принцессы».

Проект реконструкции музея, разработанный архитектурной мастерской Евгения Тоскина (ООО «АМТ проект» г. Бийск, г. Новосибирск), в 2004 году удостоен приза конкурса градостроительства, архитектуры и дизайна «Золотая капитель».

Общая стоимость строительства, согласно предоставленного сводного сметного проекта, составила 750 млн. рублей. В 2008-2012 годы на финансовые средства, пожертвованные ОАО «Газпром», была проведена реконструкция здания музея, построены дополнительные площади под фрондохранилище, экспозиции и выставки.

Жителям города и республики, гостям из других регионов после окончания реконструкции представлены научно-обоснованные экспозиции и временные выставки, рассказывающие о различных аспектах истории и культуры Горного Алтая.

Возвращение «Укокской принцессы» из Института археологии и этнографрии Сибирского отделения РАН в Республику Алтай и передача на хранение в Национальный музей имени А.В. Анохина стало уникальным событием для Республики Алтай и России (согласно с условиями соглашения возвращена была только мумия, а сопроводительный инвентарь погребений и мужская мумия с Укока остались в городе Новосибирске).

В соответствии с профессиональными и этическими нормами с учетом интересов и верований коренного населения Республики Алтай, в Национальном музее имени А.В. Анохина мумия была размещена в специальном помещении мавзолее с определенным температурно-влажностным режимом, автономной системой безопасности, хранения и доступа к саркофагу. Кроме того, музей изготовил специальный саркофаг - витрину для хранения и экспонирования мумии со встроенным прибором контроля влажности воздуха Mini Clima «EBC».

В отдельном помещении, называемом мавзолеем, развернута экспозиция «Комплекс плато Укок». Центральным звеном экспозиции, предоставляемой для обозрения посетителей, является реконструкция погребения «Укокской принцессы» в саркофраге и деревянном срубе восковой (пластиковой) фригуры «только что погребенной женщины» в сопровождении шести лошадей с полным комплектом сбруи. Имитируется ситуация момента ее захоронения, когда совершаются последние обряды и идет прощание с родственниками и соплеменниками. Фигура принцессы облачена в новоделы, точно копирующие реальные вещи из погребения кургана 1 могильника Ак-Алаха 3: головной убор, кофта-рубаха, юбка, сапоги-чулки, украшения. В «хозяйственном» отсеке размещены блюда-столики, сосуды из глины, рога, дерева, нож, курильница. За срубом помещены погребения 6 лошадей.

При входе в зал (мавзолей) сооружена особая стеклянная площадка с глубокой вертикальной нишей (ямой), на дне которой посетитель увидит реконструкцию погребального обряда. Многое из богатого и разностороннего вещевого комплекса: посуда (деревянные, глиняные, роговые, серебряные сосуды), предметы быта и утварь (зеркала, ножи), вооружение (кинжалы, чеканы, части горитов луков, наконечники стрел и т.д.), украшения (серьги, бусы, гривны, поясные пластинки, шпильки, накосники и т.д.), украшают экспозицию и являются 
важным звеном целостного показа всего археологического материала и отражают сложные процессы, происходившие в регионе за период, начиная от эпохи энеолита до средневековья. В настоящее время Национальный музей Республики Алтай имени А.В. Анохина располагает лишь небольшой частью материалов, полученных в результате раскопок 1990-1995 годах на Укоке. Это коллекция из кургана 1 могильника Ак-Алаха 1 и ряд вещей из памятников Бертек 1, 3, 10, 27, 33, 34.

Данные экспонаты размещены в различного типа витринах по всей площади зала согласно хронологическому и тематическому подбору.

Возвращение мумии не могло не наложить отпечаток на внутреннюю жизнь музея. С одной стороны, оно улучшило условия хранения и экспонирования всех коллекций (специальное фондохранилище, оборудование, инженерные системы, новые экспозиционные залы). С другой стороны, особый статус «Укокской принцессы» поставил перед руководством и сотрудниками новые вопросы, которые потребовали серьезных размышлений.

Алтайская интеллигенция позитивно восприняла факт возвращения мумии, страсти вокруг «принцессы» на некоторое время утихли. Многие представители других наций, проживающих в Горном Алтае, а также некоторая часть алтайцев выступали за то, чтобы сделать мумию общедоступной для показа всем желающим. В ответ на обращение сотрудники музея согласились выставлять мумию два раза в неделю. Это новость прошла спокойно, без каких-либо страстей.

Тема о проклятии «принцессы» вновь стала обсуждаться общественностью после чрезвычайных ситуаций в республике: наводнения в конце мая и аномального града в июле 2014 года. Эти природные явления причинили региону многомиллионный ущерб, при этом в результате наводнения погибли люди, а изза града травмы получили несколько человек. Музей оказался в фокусе пристального внимания со стороны общественности, стал объектом «проклятий» для пострадавших, хранящим, как говорили, «вселенское зло». Центральные телевизионные каналы «раздули» тему проклятия мумии практически на весь мир. С разных концов страны и из-за рубежа в музей стали поступать различного содержания письма и звонки (с угрозами, уговорами, просьбами).

В начале августа 2014 года по инициативе общественного деятеля С. Кыныева, называющего себя «белым шаманом», начался сбор подписей за возвращение мумии на Укок и перезахоронении мумии. Было собрано более 20 тысяч подписей (10\% от всего населения). Велись дебаты, собирались советы старейшин и т.д. К движению Кыныева присоединились различные инициативные группы из разных регионов с громко кричащими названиями, например, «Чрезвычайный комитет по спасению России, Комиссия по предотвращению насильственных действий» (г. Самара) и т.д.

Более того, в 2016 году С. Кыныев подал иск в суд на музей по делу о перезахоронении мумии (ожидалось, что от желающих поучаствовать в историческом судебном процессе не будет отбоя, но поддержать «шамана» никто не пришел).

Руководство Национального музея имени А.В. Анохина считало, что если вернуть принцессу на плато Укок, то мумия попросту разрушится, поскольку повторить природные условия, благодаря которым она сохранялась в течение более двух тысяч лет, представляется мало возможным. Большинство населения также соглашалось с тем, что музей ничуть не хуже кургана в высокогорье, а люди, которые хотят ее перезахоронить, занимаются самопиаром. 
Суд счел требование о перезахоронении невозможным, так как это может привести к утрате мумии, которая является уникальным научным и культурным объектом.

В течение первых лет после возвращения (2012-2016) мумия находилась в зале «Комплекс плато Укок» в закрытом саркофаге. В силу научной ценности «Укокской принцессы» и ее мировой известности, отказ от открытого экспонирования вызывал недовольство посетителей разных возрастов. С момента открытия музея после реконструкции в 2012 году, сотрудники ежедневно сталкивались с сотнями посетителей, большая часть которых желала увидеть сенсационную находку.

В 2016 г. по специальному приглашению музея в г. Горно-Алтайске работали специалисты Всероссийского научно-исследовательского центра биомедицинских технологий Федерального государственного бюджетного научного учреждения ВИЛАР (НИЦ БМТ ФГБНУ ВИЛАР, г. Москва). Специалисты выполнили ряд медико-биологических работ по оценке состояния. Надо отметить, что это было вторичное обследование состояния мумии специалистами центра, первое было в 2013 г.

После тщательного обследования, ученые заявили о хорошей сохранности мумии и возможности её экспонирования на непродолжительное время. При экспонировании было рекомендовано ограничить продолжительность показа не более 3-х часов при соблюдении заданных параметров температуры, влажности и освещённости (освещение должно быть рассеянным, видеосъёмка и фотосъёмка с использованием фотовспышки и дополнительного освещения запрещены; в объеме саркофрага постоянно должны поддерживаться значения температуры воздуха в диапазоне $+16-18^{\circ} \mathrm{C}$ и относительной влажности воздуха $60 \pm 5 \%$.).

Учитывая Конституционное право каждого гражданина на доступ к культурным ценностям, музей с 2016 года предоставил возможность посетителям увидеть мумию женщины.

Следуя традициям и обычаям алтайского народа, музей составил график экспонирования мумии. Надо отметить, что в дни и часы показа «Укокской принцессы» увеличивается поток посетителей. Участились случаи религиозного паломничества, преподнесения специальных даров (собирается целая коллекция одежды, тканей, картин с ее изображением). Она стала главным туристическим объектом региона, символом возрождения национальной культуры.

\section{Әдебиеттер тізімі/ Список литературы}

1. Еркинова Р.М. Из истории национального музея: как помогла Принцесса Укока // Анохинские чтения. Материалы VI-VII научных конференций, посвященных 140-летию А.В. Анохина (27-30 октября 2009 г.) и 95-летию со дня образования БУ РА «Национальный музей имени А.В. Анохина» (23-26 октября 2013 г.) / Под ред. Р.М. Еркиновой, Э.А. Белековой, Т.И. Полтевой, Э.А. Чулуновой. - Горно-Алтайск, 2013. - С. 132-139.

2. Молодин В.И., Полосьмак Н. В., Чикишева Т. А. и др. Феномен алтайских мумий. - Новосибирск: Изд-во Института археологии и этнографии СО РАН, 2000. - 318 с.

3. Налчаждян А.А. Этнопсихология. - Спб: Питер, 2004. - 381 с.: илл.

4. Пилипенко А. С., Трапезов Р. О., Полосьмак Н. В. Молекулярно-генетический анализ останков людей из погребения 1 кургана 1 могильника Ак-Алаха 3 // Археология, этнография и антропология Евразии. - 2015. - Т. 43. - № 2. - С. 138-145.

5. Плетц Г., Соенов В.И., Константинов Н.А., Робинсон Э. Международное значение репатриации «Укокской Принцессы» (готова ли российская археология к диалогу с коренными народами?) // Древности Сибири и Центральной Азии. Сборник научных трудов, посвященный юбилею В.И. Соенова. - Горно-Алтайск: ГАГУ, 2004. - № 7 (19). - С. 17-45.

6. Полосьмак Н. В. Всадники Укока. - Новосибирск: Инфолио-пресс, 2001. - 334 с. 
7. Руденко С. И. Культура населения Горного Алтая в скифское время. - М.; Л., 1953. - 401 с.

8. Чикишева Т. А., Полосьмак Н. В., Зубова А. В. Новые данные о погребальном комплексе кургана 1 могильника Ак-Алаха 3 // Археология, этнография и антропология Евразии. - 2015. - № 1 (61). - C.144-154.

\section{Reference}

CHikisheva, Polos'mak, Zubova 2015 - CHikisheva, TA, Polos'mak, NV, Zubova, AV 2015, Novye dannye o pogrebal'nom komplekse kurgana 1 mogil'nika Ak-Alaha 3, Arheologiya, ehtnografiya i antropologiya Evrazii, № 1 (61), P.144-154. (CHikisheva, TA, Polos'mak, NV, Zubova, AV 2015, New data on the burial complex mound 1 burial ground AK-alakha 3, Archeology, Ethnography and anthropology of Eurasia, № 1 (61), P.144-154). (in Rus).

Erkinova 2013 - Erkinova, RM 2013, Iz istorii nacional'nogo muzeya: kak pomogla Princessa Ukoka, Anohinskie chteniya. Materialy VI-VII nauchnyh konferencij, posvyashchennyh 140-letiyu A.V. Anohina (27-30 oktyabrya 2009 g.) i 95-letiyu so dnya obrazovaniya BU RA «Nacional'nyj muzej imeni A.V. Anohina» (23-26 oktyabrya 2013 g.), Pod red. RM Erkinovoj, EhA Belekovoj, TI Poltevoj, EhA. CHulunovoj, Gorno-Altajsk, P.132-139. (Erkinova, RM 2013, Iz istorii nacional'nogo muzeya: kak pomogla Princessa Ukoka, Anohinskie chteniya. Materialy VI-VII nauchnyh konferencij, posvyashchennyh 140-letiyu A.V. Anohina (27-30 oktyabrya 2009 g.) i 95-letiyu so dnya obrazovaniya BU RA «Nacional'nyj muzej imeni A.V. Anohina» (23-26 oktyabrya 2013 g.), Pod red. RM Erkinovoj, EhA Belekovoj, TI Poltevoj, EhA. CHulunovoj, Gorno-Altajsk, P.132-139). (in Rus).

Molodin, Polos'mak, CHikisheva 2000 - Molodin, VI, Polos'mak, NV, CHikisheva, TA i dr. Fenomen altajskih mumij, Novosibirsk Izd-vo In-ta arheologii i ehtnografii SO RAN, 318 p. (Molodin, VI, Polos'mak, NV, CHikisheva, TA i dr. The phenomenon of Altai mummies, Izd-vo In-ta arheologii i ehtnografii SO RAN, Novosibirsk, 318 p). (in Rus).

Nalchazhdyan 2004 - Nalchazhdyan, AA 2004, EHtnopsihologiya, Piter, Saint-Petercburg, 381 p. (Nalchazhdyan, AA 2004, Ethnopsychology, Piter, Saint-Petercburg, 381 p). (in Rus).

Pilipenko, Trapezov, Polos'mak 2015 - Pilipenko, AS, Trapezov, RO, Polos'mak, NV 2015, Molekulyarno-geneticheskij analiz ostankov lyudej iz pogrebeniya 1 kurgana 1 mogil'nika AkAlaha 3, Arheologiya, ehtnografiya i an-tropologiya Evrazii, T.43, №2, P.138-145. (Pilipenko, AS, Trapezov, RO, Polos'mak, NV 2015, Molecular genetic analysis of human remains from the burial of 1 mound 1 burial of AK-alakh 3, Archeology, Ethnography and anthropology of Eurasia, T.43, №2, P.138-145). (in Rus).

Pletc, Soenov, Konstantinov 2004 - Pletc, G, Soenov, VI, Konstantinov, NA, Robinson, Eh 2004, Mezhdunarodnoe znachenie repatriacii «Ukokskoj Princessy» (gotova li rossijskaya arheologiya k dialogu s korennymi narodami?), Drevnosti Sibiri i Central'noj Azii. Sbornik nauchnyh trudov, posvyashchennyj yubileyu V.I. Soenova, Publishing house of GAGU, Gorno-Altajsk, №7(19), P.17-45). (Pletc, G, Soenov, VI, Konstantinov, NA, Robinson, Eh 2004, international importance of repatriation of the «Ukok Princess» (is Russian archaeology ready for dialogue with indigenous peoples?), Antiquities of Siberia and Central Asia. Collection of scientific works dedicated to the anniversary of V.I. Soenov, Publishing house of GAGU, Gorno-Altajsk, №7(19), P.17-45). (in Rus).

Polos'mak 2001 - Polos'mak, NV 2001, Vsadniki Ukoka, Infolio-press, Novosibirsk, 334 p. (Polos'mak, NV 2001, The Riders Of Ukok, Infolio-press, Novosibirsk, 334 p). (in Rus).

Rudenko 1953 - Rudenko, SI 1953, Kul'tura naseleniya Gornogo Altaya v skifskoe vremya, Moscow; Leningrad, 401 p. (Rudenko, SI 1953, Culture of the population of the Altai Mountains in the Scythian time, Moscow; Leningrad, 401 p). (in Rus). 